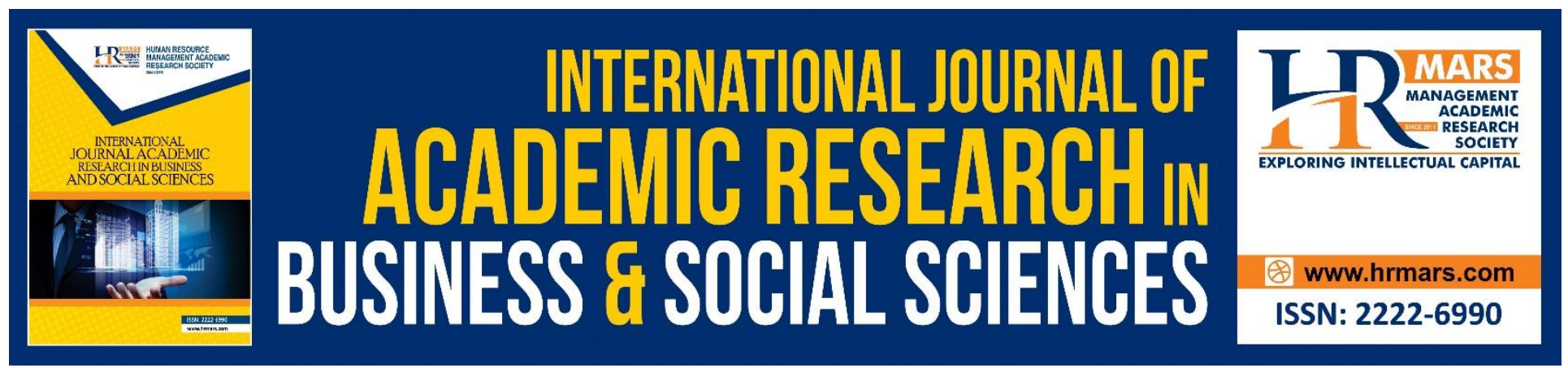

\title{
Perceptions of Service Quality and Behaviour Intentions of Campus Fitness Center Users in Malaysia and Thailand
}

Aminuddin Yusof, Arporn Popa, Soh Kim Geok

To Link this Article: http://dx.doi.org/10.6007/IJARBSS/v8-i12/5005

DOI: $10.6007 /$ IJARBSS/v8-i12/5005

Received: 17 Oct 2018, Revised: 16 Nov 2018, Accepted: 29 Nov 2018

Published Online: 18 Dec 2018

In-Text Citation: (Yusof, Popa, \& Geok, 2018)

To Cite this Article: Yusof, A., Popa, A., \& Geok, S. K. (2018). Perceptions of Service Quality and Behaviour Intentions of Campus Fitness Center Users in Malaysia and Thailand. International Journal of Academic Research in Business and Social Sciences, 8(12), 187-197.

Copyright: (C) 2018 The Author(s)

Published by Human Resource Management Academic Research Society (www.hrmars.com)

This article is published under the Creative Commons Attribution (CC BY 4.0) license. Anyone may reproduce, distribute, translate and create derivative works of this article (for both commercial and non-commercial purposes), subject to full attribution to the original publication and authors. The full terms of this license may be seen

at: http://creativecommons.org/licences/by/4.0/legalcode

Vol. 8, No. 12, 2018, Pg. 187 - 197

Full Terms \& Conditions of access and use can be found at http://hrmars.com/index.php/pages/detail/publication-ethics 


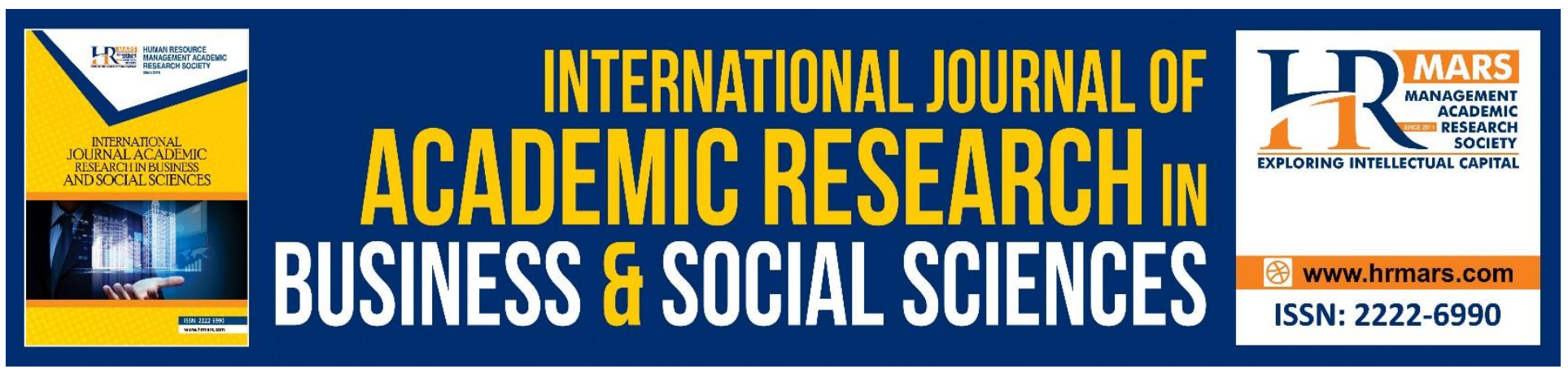

\title{
Perceptions of Service Quality and Behaviour Intentions of Campus Fitness Center Users in Malaysia and Thailand
}

\author{
Aminuddin Yusof ${ }^{\star}$, Arporn Popa ${ }^{2}$, Soh Kim Geok ${ }^{3}$ \\ 1,3 Faculty of Educational Studies, Universiti Putra Malaysia, 43400 UPM Serdang, Selangor Darul \\ Ehsan, Malaysia \\ ${ }^{2}$ Health and Sport Science Department, Mahasarakham University, Thailand
}

\begin{abstract}
The study was designed to determine the perceptions of service quality and future intention to use campus fitness centers in Universiti Putra Malaysia (UPM) and Mahasarakham University, Thailand. Data were collected using questionnaires distributed to 450 campus fitness center users comprising of faculty and staff from Mahasarakham university $(n=250)$ and one university in UPM $(n=200)$ were selected to participate as subjects in the study. The questionnaire consisted of items based on the Likert-scale Service Quality Assessment Scale (SQAS) developed by Lam, Zhang and Jensen (2005). Behavioral intention is based on three questions modified from Cunningham and Kwon (2003) and Zeithaml et al. (1996). Results showed significant differences $(p<.05)$ in perceptions of overall fitness facility service quality and overall program service quality between users in UPM and Mahasarakham universities. The results showed a statistically significant difference $(p<.05)$ in terms of behavior intentions of users in UPM and Mahasarakham University with those in UPM reporting higher intentions to renew their membership and recommend the recreation center to other people. Based on the results, it was concluded that good quality service would influence fitness center users at both universities to recommend the fitness center to other people and influence them to renew their membership.
\end{abstract}

Keywords: Service Quality, Campus Fitness Center, Behaviour Intentions

\section{Introduction}

In Malaysia and Thailand, universities are building campus fitness facilities (Yusof, 2013; Senakham, 2010) due to the concern that students are inactive and leading a sedentary lifestyle which can have a negative physiological and psychological effects. Studies have reported that high school students report a decrease in physical activity after finishing high school and many students are leading a sedentary lifestyle upon entering university (Caspersen, Pereira, \& Curran, 2000). Universities in 
Malaysia and Thailand are concern that the inactive lifestyle among students may developed into higher risk of death due to chronic disease such as cardiovascular disease as well as depression and anxiety-related problems (Camacho, Roberts, Lazarus, Kaplan \& Cohen, 1991). An active lifestyle among students in universities has also been shown to have a positive effect on academic achievement. (Al-Ahmed, Yusof \& Shah, 2015). Many colleges and universities in both countries provide services such as fitness centers and health and wellness programs to the student population. These services not only provide opportunities for physical fitness to students but also improve the overall health well-being of students. In Malaysia, even though the government has spent a large allocation of funding to encourage sports and physical activities, the participation of students in sport and physical activities is still low (Yusof \& Shah, 2007). To encourage an active lifestyle, national policies such as the National Sports Policy has been established in Malaysia (Ministry of Youth \& Sport Malaysia, 2009) aimed at creating a sporting culture among Malaysians. Similar policy was also created in Thailand in the form of the National Sport Development Plan (Ministry of Tourism \& Sports Thailand, 2017) with the goal of promoting healthy lifestyles, good ethics, and sportsmanship among people of Thailand. The establishment of campus fitness centers in universities in Thailand and Malaysia is part of the strategy to achieve the objectives of the national sport policies in both countries.

The aim of most fitness centers is not only to increase membership but most importantly is to get existing members to renew their membership. Since the cost of attracting new members is actually costlier than maintaining current members to renew their membership (Al-Awadi, 2002), retention of members and measuring their loyalty are increasingly important (Smith, Murray and Howat, 2014). One way of retaining members is by providing excellent service (Avourdiadou and Theodorakis, 2014). A satisfied fitness center customer will have higher loyalty and will be more likely to renew their membership. Members' retention is related with loyalty which in turn is related to how they perceived the organisation's service quality. This leads to satisfaction if the customers satisfied with the service provided by the provider. It is important that that customer satisfaction be constantly monitored as this is key to loyalty and retention (Kotler, 2009).

Service quality is defined by Kotler, Adam, Brown, and Armstrong (2006) as "delivering superior value to customers and subsequently improving customers and society's wellbeing as part of societal marketing concepts" (p.108). Since services provided to members are intangible and cannot be touched or tasted, the services are valued as experiences, and service quality is determined by postexperience customer research (Robinson, 2003). Members' perceptions and experiences directly influence their future behavioural intentions of renewing their membership. "When customers perceive that they are receiving service quality worth for their money, they believe they are receiving good value, which in the long run increases their loyalty to the service provider" (Venetis and Ghauri, 2004, p. 1980).

According to Zeithaml and Bitner (2000), there two aspects of service quality: tangible and intangible aspects. The tangible aspect of service quality covers factors related with the physical aspects of a fitness facility such as training equipment, design and layout of the facility, training accessories, the 
supply of towels, dumbbells and barbells lockers and other accessories and maintenance of facility and equipment. Services provided at a fitness center are the intangible aspects which cannot tested and standardized. There are few cues that a customer can rely on to judge the quality of a service (Parasuraman et al 1985; Zeithaml, Berry and Bitner, 2000) but include aspects such as knowledge and skill of the staff and how they interact with users. The convenience of location, hours of operation, availability of parking as well as parking lot safety are part of the intangible aspects.

Due to the substantial amount of money is spent building fitness facilities on campus, university administrators need to ensure the usage of these facilities are at an optimal level. Thus, it is important for university management to measure the perceptions of service quality of these facilities. No study has been done to examine the perception of service quality at campus fitness center facilities as well as how this perception is related with behavioural intentions in terms of future usage. Hence, to fill this void, the purpose of this study is to compare campus fitness center user's perceptions of service quality and future intention to use campus fitness centers in Universiti Putra Malaysia (UPM) and Mahasarakham University, Thailand. The research questions for this study are:

1) What are the perceptions of overall program service quality among fitness center users in UPM and Mahasarakham University?

2) Are there differences in perception of overall program service quality between campus fitness center users in UPM and Mahasarakham University?

3) What are the perceptions of overall facility service quality among fitness center users in UPM and Mahasarakham University?

4) Are there differences in perception of overall facility service quality between campus fitness center users in UPM and Mahasarakham University?

5) What are the behavior intentions among fitness center users in UPM and Mahasarakham University?

6) Are there differences in behavior intentions among fitness center users in UPM and Mahasarakham University?

\section{Sample and Data Collection}

Using convenient sampling technique, a total of 450 campus fitness center users comprising of faculty and staff from one university in Mahasarakham university $(n=250)$ and one university in UPM $(n=200)$ were selected to participate as subjects in the study. The distribution of the subjects in terms of gender is shown in Table 1.

Table 1: Gender of Subjects
UPM
Mahasarakham university

\begin{tabular}{lllr}
\hline Gender: & Male & 140 & 189 \\
& Female & 60 & 61 \\
& Total & $\mathbf{2 0 0}$ & $\mathbf{2 5 0}$
\end{tabular}


INTERNATIONAL JOURNAL OF ACADEMIC RESEARCH IN BUSINESS AND SOCIAL SCIENCES

Vol. 8, No. 12, Dec, 2018, E-ISSN: 2222-6990 @ 2018 HRMARS

\section{Instruments}

\section{Section A: Demographic Background}

The questionnaire consists of several parts. The first is question about demographic data such as age, gender, marital status, employment, membership status, frequency and duration of using the fitness center facility.

\section{Section B: Service Quality Assessment Scale (SQAS)}

The data collection instrument was the 40 items Likert-scale Service Quality Assessment Scale (SQAS) developed by Lam, Zhang and Jensen (2005). The reliability for all constructs items was ranging from 0.71 to 0.85 for this instrument and also the convergent validity of the measure was achieved which is each of the construct items ranging from .62 to .92 (Taghizadeh, Ghorbani and Begnam, 2015). This instrument is designed to evaluate service quality of health clubs and fitness centers by patrons and consists of six dimensions of service quality: staff, programme, locker room, physical facility, workout facility, and childcare.

\section{Section C: Behaviour Intentions}

For the Malaysian fitness center users, behavioral intention is based on three questions modified from Cunningham and Kwon (2003). However, for Thai fitness center users, future intention is measured using two subscales proposed by Zeithaml et al. (1996) were used: word-of-mouth communications (e.g., saying positive things about the facility to others) and repurchase intentions (e.g., membership renewal in the near future). Data were analysed using descriptive statistics (mean, std. deviation and frequency analysis), correlations and t-tests.

\section{Results}

Descriptive statistics conducted to examine a general profile of the fitness center users in UPM and in Mahasarakham. In terms of age, table 2 shows that the majority of the subjects from fitness centers in both universities are in the 18-25 years old age group.

Table 2: Age of Subjects

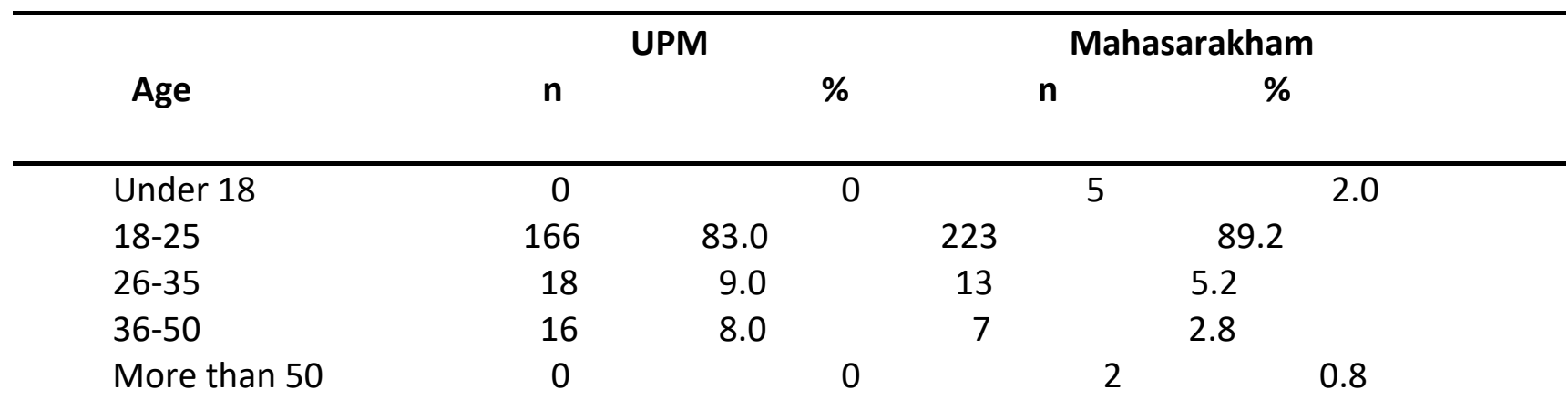

In terms of the frequency of using the campus fitness center, table 3 shows that majority of the subjects in UPM (83\%) only visit the campus fitness center two times or less in a week. No subject visited the campus fitness center 7 or more times in a week. For subjects in Mahasarakham 
INTERNATIONAL JOURNAL OF ACADEMIC RESEARCH IN BUSINESS AND SOCIAL SCIENCES Vol. 8, No. 12, Dec, 2018, E-ISSN: 2222-6990 C 2018 HRMARS

University, the majority visited the campus fitness center at least 3 times a week with $21.2 \%$ of the subjects visited the facility at least 5 times a week compared with only $2.0 \%$ doing the same in UPM. Thus, the results shows a different in terms of the usage frequency between UPM and Mahasarakham fitness center users with the latter being more likely to frequent and use the fitness center facility.

The first research question seeks to examine the perceptions of overall program service quality among campus fitness center users in UPM and Mahasarakham University. The results is shown in Table 3. Fitness center users in Mahasarakham have a slightly higher perceptions of overall program service quality compared with users at UPM.

Table 3: Perceptions of Overall Program Service Quality

N Mean Sd

\begin{tabular}{llll} 
Mahasarakham & 237 & 25.11 & 4.99 \\
UPM & 200 & 24.44 & 4.41 \\
\hline
\end{tabular}

Research question two seeks to compare differences in perception of overall program service quality between users in UPM and Mahasarakham. Table 4 reports the result of the independent sample $t$ test which showed a statistically significant difference $(p<.05)$ in perceptions of overall program service quality between users in UPM and Mahasarakham universities. Specifically, the results showed that fitness center users in Mahasarakham $(m=25.11)$ reported to be more satisfied than their UPM $(m=24.14)$ counterparts in terms of the variety of programs and activities are being offered, adequacy of space, convenience of time and schedule, appropriateness of class size, availability of appropriate activities as well as quality content of programs. It is possible that besides having a spacious gym floor to conduct activities, Mahasarakham fitness center users perceived the campus fitness center to have more variety of different activities offered besides the normal free weights activities conducted at other fitness centers such as personal training class and exercise class activities involving Zumba exercise.

Table 4: T-test for Differences in Perceptions of Overall Program Service Quality

\begin{tabular}{lllllll}
\hline & N & Mean & Sd & T & df & Sig \\
\hline Mahasarakham & 237 & 25.11 & 4.99 & 2.192 & 435 & $.028^{*}$ \\
UPM & 200 & 24.14 & 4.11 & & & \\
\hline
\end{tabular}

$* p<.05$ 
INTERNATIONAL JOURNAL OF ACADEMIC RESEARCH IN BUSINESS AND SOCIAL SCIENCES Vol. 8, No. 12, Dec, 2018, E-ISSN: 2222-6990 C 2018 HRMARS

Table 5 examines the perceptions of overall facility service quality between fitness center users in UPM and Mahasarakham. This is to address research question three. The results show fitness center users in Mahasarakham ( $m=37.48$ ) have a higher perceptions of overall program service quality compared with users at UPM $(m=30.77)$. The results suggest that the fitness center should be concerned with overall facility service quality such as the convenience of location, hours of operation, availability of parking as well as parking lot safety. It also refers to temperature control, lighting and pleasantness of the facility in terms of environmental friendly.

Table 5: Perceptions of Overall Facility Service Quality

N Mean Sd

$\begin{array}{llll}\text { Mahasarakham } & 244 & 37.48 & 8.93 \\ \text { UPM } & 200 & 30.77 & 3.78\end{array}$

Research question four compare the differences in perceptions of overall facility service quality between fitness center users in UPM and Mahasarakham. An independent sample t-test was performed and the results (Table 6 ) showed a statistically significant difference $(p<.05)$ in perceptions of overall fitness facility service quality between users in UPM and Mahasarakham universities. The results suggest fitness center users in Mahasarakham perceived the fitness center as being more conveniently located as well as user friendly than those reported by UPM users in terms of secured parking facilities are provided with guaranteed secure parking from any theft, accident or otherwise. In addition, the operation of the fitness center hours are also convenient for students and staff to use during their free time.

Table 6: T-test for Differences in Perceptions of Overall Facility Service Quality

\begin{tabular}{lllllll}
\hline & N & Mean & Sd & T & df & Sig \\
\hline Mahasarakham & 244 & 37.48 & 8.93 & 9.928 & 442 & $.001^{*}$ \\
UPM & 200 & 30.77 & 3.78 & & & \\
\hline
\end{tabular}

$* p<.05$

Research question five examines the behaviour intentions of fitness center users. Behaviour intention is defined as the concept of trying to perform a behavioral goal or a given behavior (Ajzen, 1991). In this study two questions were used to measure behavior intentions. The first asked respondents whether will recommend the recreation center to other people while the second asked respondents whether they have the intention to renew their membership. The results as shown in Table 7 suggest 
INTERNATIONAL JOURNAL OF ACADEMIC RESEARCH IN BUSINESS AND SOCIAL SCIENCES

Vol. 8, No. 12, Dec, 2018, E-ISSN: 2222-6990 C 2018 HRMARS

UPM fitness center users have a higher intentions $(m=4.02)$ than users at Mahasarakham University $(\mathrm{m}=3.73)$.

Table 7: Behaviour Intentions

N Mean Sd

$\begin{array}{llll}\text { Mahasarakham } & 250 & 3.73 & .05 \\ \text { UPM } & 200 & 4.02 & .04\end{array}$

Table 8 shows the results of the differences in intentions between users in UPM and Mahasarakham universities. The results showed a statistically significant difference $(p<.05)$ in terms of behavior intentions of users in UPM and Mahasarakham University with those in UPM reporting higher intentions to renew their membership and recommend the recreation center to other people.

Table 8: T-test for Differences in Behaviour Intentions

\begin{tabular}{lllllll}
\hline & N & Mean & Sd & T & df & Sig \\
\hline Mahasarakham & 250 & 3.73 & .05 & -0.405 & 448 & $.001^{*}$ \\
UPM & 200 & 4.02 & .04 & & & \\
\hline
\end{tabular}

${ }^{*} p<.05$

\section{Discussion}

This study assumes that service quality and would influence behavior intention to frequent the fitness center at both universities. This assumption was supported by the results of the study which showed good quality service would influence fitness center users at both universities to recommend the fitness center to other people and influence them to renew their membership. Thus, it was concluded that the quality of service provided directly influence behavior intention of fitness center users. Based on this finding, it is recommended for fitness center at both universities to regularly evaluate the quality of service provided to users and to establish and maintain high quality standards. Based on the suggestion of Zeithaml and Bitner (2003), fitness center users at both universities should be concerned in providing service quality in terms of the tangible and intangible aspects of service quality.

In this study, there are differences in perceptions of overall program service quality between Mahasarakham $(m=37.48)$ and users at UPM $(m=30.77)$. The overall program service quality dimension as proposed by Kim and Kim (1995) refers to whether different types of programs and activities are organised such as sport programs, family activities and community. Overall program service quality also includes attributes such as adequacy of space, convenience of time and schedule, 
appropriateness of class size, availability of appropriate activities as well as quality content of programs. Since users at UPM gave lower scores to the fitness center at the University for this Dimension, the fitness center needs to identify the needs of the fitness center users with regard to these elements. Since the fitness industry is growing in both Malaysia and Thailand, it is important for both fitness centers to be competitive in terms of providing a differentiated product offering. Based on Parasuraman et al, 1988, this would mean providing a fitness program different from other fitness centers. Thus, it is recommended that both fitness centers study user needs and develops a program which is able to meet the needs of users but different from the rest of the competitors.

Based on the recommendation of Butcher, Sparks and O'Callaghan (2001), fitness center users' intention to renew their membership or to recommend others to use the fitness facility show the positive effects of satisfaction on loyalty. One aspect of customer loyalty and retention in the fitness industry is the ability of a fitness center to provide members with a good workout regardless of physical state and ability. Serious fitness enthusiast know what they want each time the visit they fitness centers and if the center is able to provide what they need and want, they are more likely to retain their membership for a long duration of time. There is a need for administrators of both fitness centers in UPM and Mahasarakham to identify these users as they have high expectations on their outcome of each visit. Perhaps an environment that showcase good images of fit and healthy bodies can be placed at strategic locations to serve as forms of motivations. The fitness image of the staff as well as the fitness instructors need to highlight and placing positive image of healthy body around the club. In addition, personal trainers must be trained to convey realistic goals to users and be sincere in helping them reach their goals as well as providing honest evaluation of the progress of fitness center members towards meeting their goals.

\section{Conclusion}

A student lifestyle during years in a university is crucial in determining whether the student will engage in healthy behaviour in adulthood (Sax, 1997). The time spent in a university is the period in which a student develops an active or sedentary lifestyle in the future. Death and diseases among adults are significantly linked to the type of behaviours students engaged in while they are in college. Thus, it is important for fitness center administrators at universities in Thailand and Malaysia to ensure the quality of the services provided at the fitness centers. This is to ensure effective recruitment and retention of students using the facilities. The campus fitness center serves as a place for students to create healthy behaviors while they are studying in universities, so they may continue engaging in a healthy lifestyle when they graduate and throughout their adulthood. This would help achieve the objectives of creating a sporting culture among people in both countries.

\section{References}

Al-Ahmed, M., Yusof, A., \& Shah, P.M. (2015). Attitude, sports participation and academic performance of undergraduate student-athletes in Saudi Arabia. Journal of Physical Education and Sport, 16 (3), 1000-1004.

Al-Awadi, A. (2002). A Proposed Model of Consumer Loyalty in the Retailing Sector Based on the Kuwaiti Experience. Total Quality Management, 13 (7), 1035-1046. 
INTERNATIONAL JOURNAL OF ACADEMIC RESEARCH IN BUSINESS AND SOCIAL SCIENCES Vol. 8, No. 12, Dec, 2018, E-ISSN: 2222-6990 @ 2018 HRMARS

Avourdiadou, S. \& Theodorakis, N. (2014). The development of loyalty among novice and experienced customers of sport and fitness centers. Sport Management Review, 17(4), 419-431

Butcher, K., Sparks, B. and O'Callaghan, F. (2001). Evaluative and Relational Influences on Service Loyalty, International Journal of Service Industry Management, 12(4), pp. 310-327.

Camacho, T.C., Roberts, R. E., Lazarus, N. B., Kaplan, G. A., \& Cohen, R. D. (1991). Physical activity and depression: Evidence from the alameda county study. American Journal of Epidemiology, 143, 220-231.

Caspersen CJ, Pereira MA \& Curran KM. (2000). Changes in physical activity patterns in the United States, by sex and cross-sectional age. Medicine and Science in Sports and Exercise. 32(9), 1601-1609.

Cunningham, G.B. and Kwon, H. (2003) The Theory of Planned Behaviour and Intentions to Attend a Sport Event. Sport Management Review, 6, 127-145.

Kim, D., \& Kim, S. Y. (1995). QUESC: An instrument for assessing the service quality in sport and leisure center customers. Journal of Sport Management, 9, 208-220.

Kotler, P. (2009). Marketing management-analysis, planning, implementation and control. (9th Ed.). Prentice-Hall Inc.

Kotler, P., Adam, S., Brown, L., and Armstrong, G. (2006). Principles of Marketing, 3rd Edition, Pearson Education Australia, French Forest, New South Wales.

Lam, E., Zhang, J., \& Jensen, J. (2005). Service quality assessment scale (SQAS): as instrument for evaluating service quality of health fitness clubs. Measurement in Physical Education and Exercise Science, 9:79-111

Ministry of Youth \& Sport Malaysia (2009). National Sports Policy. Kuala Lumpur: Author.

Ministry of Tourism \& Sport Thailand (2017). The sixth national sports development plan. Bangkok, Thailand: Author.

Parasuraman, A., Zeithaml, V. A. \& Berry, L. L. (1988). SERVQUAL: A multiple-item scale for measuring consumer perceptions of service quality. Journal of Retailing, 64(1), 12-40.

Quintana, J. (2006). The greatest blind spot: customer perception. Retrieved 3.11.2015, from MY Customers.com: http/www.mycustomers.com/cgi-bin/item.cgi?id=132560\&u=pnd\&phnd

Robinson, L. (2003). The business of sport. In B. Houlihan (Ed.), Sport and society. London: Sage.

Sax, L. (1997). Health trends among college freshmen. Journal of American College Health, 45, 252262.

Senakham, T. (2010). Customers' expectations of service quality in the Thai University fitness centers in Bangkok metropolitan area, Kingdom of Thailand. Spanish Fort: United States Sports Academy.

Smith, J., Murray, D., \& Howat, G. (2014). How perceptions of physique can influence customer satisfaction in health and fitness centers. Managing Leisure, 19(6):442-460

Taghizadeh, F. \& Ghorbani, H. O. (2015). The psychological continuum model: examination of spectators' involvement levels in the football. Sport Science, 8(1), 64-71.

Venetis, K. A. and Ghauri, P. N. (2004). Service Quality and Customer Retention: Building Long-term Relationships, European Journal of Marketing, 38 (11), pp. 1577-1598.

Yusof, A., Chuan, C.C. \& Shah, P. (2013). Academic achievement and sports involvement of Malaysian university athletes. Procedia - Social \& Behavioral Sciences, 106, 273-281. 
INTERNATIONAL JOURNAL OF ACADEMIC RESEARCH IN BUSINESS AND SOCIAL SCIENCES Vol. 8, No. 12, Dec, 2018, E-ISSN: 2222-6990 @ 2018 HRMARS

Yusof, A. \& Shah, P. (2007). Sport participation constraints of Malaysian university students. The International Journal of the Humanities, 5(3), pp 189-195

Zeithaml, V., Berry, L. and Parasuraman, A. (1996). The Behavioral Consequences of Service Quality, Journal of Marketing, 60, pp. 31-46.

Zeithaml, V. and Bitner, M. (2003). Services Marketing: Integrating Clients' Focus Across Firms. New York: McGraw-Hill. 